DOI: $10.19195 / 2353-8546.6 .10$

MAJA HARBUZIUK*

Lwowski Uniwersytet Narodowy im. Iwana Franki (Ukraina)

\title{
Scena a przedstawienie traumy historycznej: dramaty/spektakle, twórcy/odbiorcy we współczesnym teatrze ukraińskim
}

Historic trauma on the stage: dramas and plays, recipients and directors in contemporary Ukrainian theatre. The aim of this article is to analyse theatrical performances based on plays of contemporary Ukrainian authors. The analysis is made from the position of their work with traumatic (historical and modern) experience of community. A short evaluation of modern state of Ukrainian theatre is made. Ukrainian theatre as "positivist" worldview art excludes pictures and themes of traumatic experiences irrational by nature. The attention is paid to the importance of empathy mechanism in the process of elaboration of collective structural and historic traumas. It is presented how transgressive trauma comes out in the creativity of modern directors, blocking empathy mechanisms and leading to autoaggression. The paper emphasises the importance of personal experience and worldview maturity of the authors of the texts and performances, as well as their readiness and skill to cross boundaries of various stereotypes imposed by complex collective and historical traumas.

Keywords: modern Ukrainian theatre, modern Ukrainian dramaturgy, historical trauma, structural trauma, empathy

Сцена как представление исторической травмы: пьесы/спектакли, создатели/зрители в современном украинском театре. В статье сделано попытку анализа спектаклей профессиональных театров по пьесам современных украинских авторов, с позиций их работы с травматическим (историческим и современным) опытом общества. Коротко дана оценка современному состоянию украинского

Adres do korespondencji: ul. Walowa, 18, p. 22, 79008 Lwów, Ukraina. E-mail: harbuzyuk. maya16@gmail.com. 
театра как искусства в целом мировоззренчески «позитивистического», исключающего иррациональные по своей природе картины и темы травматических переживаний. Обращено внимание на важность механизмов эмпатии в процессе прорабатывания коллективных структурных и исторических травм. Продемонстрировано, как трансгрессивная травма проявляет себя в творчестве современных режиссеров, блокируя механизмы эмпатии, приводя к автоагрессии. Подчеркнуто важность личностного опыта и зрелость мировоззрения авторов текстов и спектаклей, их готовность и умение выходить за пределы разного характера стереотипов в работе со сложными коллективными историческими травмами.

Ключевые слова: современный украинский театр, современная украинская драматургия, историческая травма, структуральная травма, эмпатия

Jeżeli według Kaja Eriksona „trauma może tworzyć społeczność” ${ }^{1}$, to - zdaniem pewnych badaczy — naród ukraiński jest właśnie taką społecznością. Co więcej, niektórzy z nich uważają, że traumy historyczne stanowią jądro mentalności ukraińskiej, a usuwanie traumatycznych doświadczeń może prowadzić do utraty tożsamości narodowej ${ }^{2}$.

Niezwykle ważne procesy, które Jeffrey Aleksander nazywa „procesami kształtowania się traum"3, w warunkach totalitaryzmu zostały całkowicie zablokowane. Presja ideologiczna uniemożliwiła pojawienie się jakichkolwiek społecznych (w tym artystycznych) form reprezentacji traumy historycznej, zastępując je nieprawdziwymi, sfałszowanymi obrazami.

Z tego punktu widzenia teatr ukraiński w okresie podporządkowania totalitarnemu imperium ZSRR można uznać nie tylko za nośnik nałożonych przez władzę klisz ideologicznych, lecz także za ofiarę, która została zraniona „wymuszonym milczeniem”, „niemotą". W tym znaczeniu doświadczenie wymuszonego milczenia można potraktować nie tyle jako efekt traumy, ile jej źródło. Ta podwójna funkcja staje się indykatorem głębokości, siły i czasu trwania traumatycznego doświadczenia ukraińskiej sceny teatralnej. Zgodnie z myślą Cathy Caruth, która napisała, że „stan straumatyzowania utożsamia się z niemotą czy milczeniem”4, ciężar podwójnej traumy szczególnie mocno odbił się w dziedzinie komunikacji społecznej, zwłaszcza w teatrze. Można stwierdzić, że w przeszłości ukraińska scena teatralna nie mogła przysłużyć się ani przepracowaniu zbiorowych traum społecznych, ani walce z narzuconym z góry ich „uciszaniem”.

${ }^{1}$ K. Erickson, A New Species of Trouble: The Human Experience of Modern Disasters, New York 1994, s. 231.

2 Zob. М. Семиліт, Концепиія житттєвого шляху у контексті теорії колективної травми, http://forum.onu.edu.ua/index.php?topic=5057.0; wap2 (dostęp: 20.02.2017).

${ }^{3}$ J. Alexander, Cultural trauma and collective identity, [w:] The Meaning of Social Life. A Cultural Sociology, Oxford 2003, s. 94.

4 C. Caruth, Teoria traumy jako siła lektury. Cathy Caruth w rozmowie z Katarzyna Bojarska, rozm. przepr. K. Bojarska, „Teksty Drugie” 2010, nr 6, s. 128. 
Wraz z uchwaleniem Aktu Niepodległości Ukrainy teatr ukraiński zyskał pełną wolność wypowiedzi, jednak do dziś zauważalne są w nim brak odpowiedniego języka dla opisów wydarzeń traumatycznych, roztargnienie, a nawet dezorientacja. Możemy mówić o pewnym zjawisku genetycznie dziedziczonej „ślepoty teatru” zarówno na tragiczne wydarzenia z przeszłości Ukrainy, jak i na współczesne traumatyczne doświadczenia widza.

Nie oznacza to, że tematy kataklizmów historycznych były obce scenie ukraińskiej ostatniego dwudziestopięciolecia. Wręcz przeciwnie, w latach niepodległości Ukrainy wysiłki działaczy teatralnych były skierowane na stworzenie metatekstu o własnej przeszłości tragicznej, opartego na symbolizmie, wizji romantycznej oraz rekonstruowaniu mitologii narodowej. Ale takie "przywrócenie historii”, jak wiadomo, jest możliwe przede wszystkim w ramach pozytywistycznego światopoglądu, co podkreśla Grzegorz Niziołek w ślad za Zygmuntem Baumanem ${ }^{6}$. Dlatego teatr ukraiński z opowieści o swojej przeszłości wyeliminował elementy irracjonalne, estetykę szoku, mechanizmy dekonstrukcji. Również traumatyczne przeżycie - irracjonalne ze swej natury i niedające się logicznie wytłumaczyć - pozostawało poza uwagą i językiem teatru ukraińskiego.

Rewolucja godności (2013-2014) zapoczątkowała w teatrze ukraińskim powstanie innej narracji — „narracji traumy”. Masakra „Niebiańskiej sotni” na Majdanie, rosyjska agresja na południu i wschodzie Ukrainy — te przełomowe dla historii kraju wydarzenia postawiły społeczeństwo, kulturę i sztukę przed nowymi wyzwaniami, wśród których za najważniejsze można uznać próby uświadomienia konieczności przezwyciężania oraz przepracowania traum, zarówno zbiorowych, jak i indywidualnych. Co więcej, nowe traumatyczne doświadczenia skierowały uwagę na samoanalizę oraz samoleczenie zarówno świeżych, jak i starych, nieprzepracowanych dotąd traum historycznych. Ostry ból związany z poniesionymi stratami wywołał potrzebę stworzenia nowych metod reprezentacji i przetwarzania przeszłości.

Dzisiaj możemy mówić o dwóch podstawowych rodzajach pracy teatralnej z traumą historyczną. Pierwszy z nich to tzw. teatr społeczny, do którego zaliczamy teatr dokumentalny ${ }^{7}$ oraz teatr świadka ${ }^{8}$. Teatr tego typu jest nakierowany na pracę $\mathrm{z}$ nowo uzyskanym doświadczeniem traumatycznym ostatnich trzech lat. W takich projektach udział biorą sami świadkowie i uczestnicy wydarzeń, którzy opowiadają widzom historie swojego życia, w ten sposób uprzedmiotowiając doświadczenie traumatyczne $e^{9}$. Bez wątpienia to unikalne podejście wymaga jeszcze dogłębnych ba-

${ }^{5}$ G. Niziołek, Polski teatr Zagłady, Warszawa 2013, s. 32.

6 Ibidem, s. 31.

7 N. Worożbyt, Dzienniki Majdanu (Щоденники Майдану), Narodowy Akademicki Teatr Dramatyczny im. Iwana Franki, 2014; R\&J Saszka Bramy, Lwów 2014.

8 Projekt Mikołajówka (Миколаївка), G. Żeno, N. Worożbyt, 2015; Teatry: Teatr Uchodźca (Театр переселенця), Kijów, od 2015; PostPlayTeatr, Kijów, od 2015.

9 Teatr tego typu ma również cel psychoterapeutyczny. Szczególnie w „Teatrze przesiedleńców” w celu osiągnięcia pozytywnego psychoterapeutycznego wpływu z uczestnikami projektu pracuje profesjonalny psycholog wojskowy Oleksij Karaczynkyj. O „Teatrze jako sposobie leczenia” mówi je- 
dań, przede wszystkim jako fenomen społeczno-psychologiczny znajdujący się na przecięciu sztuki, psychologii, socjologii oraz kulturoznawstwa. Drugim rodzajem pracy teatralnej z traumą są spektakle teatrów repertuarowych według dramatów współczesnych autorów ukraińskich. Premiery z lat 2014-2016 pokazują różne strategie i skutki pracy z traumami historycznymi w spektaklach teatrów zawodowych, o czym warto mówić jako o nowym doświadczeniu sztuki scenicznej na Ukrainie.

Praca nad spektaklem Kijowskiego Akademickiego Teatru Dramatu i Komedii na Lewym Brzegu Dniepru, opartym na opowiadaniach rosyjskiego pisarza dla dzieci Jurija Kowala ${ }^{10}$, trwała zimą w latach 2013-2014, czyli równocześnie z wydarzeniami na Majdanie. Premiera sztuki odbyła się zaś 27 lutego 2014 roku - tydzień po masowych zabójstwach i kilka dni po ceremonii pogrzebowej pożegnania zmarłych. Zarówno wybór materiału, jak i nazwa spektaklu - Serdeczna uciecha lub Сzарkа z karasiami (Веселье сердечное или Кепка с карасями) - jak i rozwiązania reżyserskie zastosowane przez Dmytra Bohomazowa pozostawały na pierwszy rzut oka sprzeczne z ogólnym stanem społeczeństwa. Mimo powszechnego silnego poczucia utraty reżyser zaproponował bowiem historię o możliwości uzyskania harmonii w ludzkim świecie. Przedstawienie to było jedną z pierwszych prób pracy ze współczesnym traumatycznym doświadczeniem w ukraińskiej sztuce.

Podstawą fabuły spektaklu jest filozoficzno-liryczna opowieść głównego bohatera - współczesnego pisarza, który wspomina swoje spotkania z mieszkańcami wsi zagubionej pośród lasów, miejsca będącego swoistą „wyspą”, gdzie zamiast nienawiści, złości i wrogości panują miłość, piękno i harmonia. Co istotne, narracyjna struktura sztuki (w której „prawie nic” się nie dzieje, gdzie nie istnieje żadna kategoria konfliktu w jego tradycyjnym sensie, nie ma winnych, ofiar, nie ma też typowych bohaterów) należy do serii niekonwencjonalnych historii, o których pisze Dominick LaCapra, badając specyfikę twórczości Samuela Becketta oraz Maurice’a Blanshota i wiążąc tego typu zagadnienie z pytaniem "nieobecności” ${ }^{11}$.

W sztuce przenikają się dwa dyskursy: utopii - nieosiągalnego/utraconego, pożądanego - i traumatycznej współczesności. Łączą się one z kluczową postacią narratora, który - jak w klasycznej Freudowskiej opowieści o dziecku rzucającym i znajdującym zabawkę - przywołuje w swej pamięci obrazy z przeszłości, a opanowując je, dąży do równowagi w teraźniejszości i przyszłości. Im jaskrawsze i ja-

den z jego współzałożycieli, reżyser Georg Genoux (Г. Жено, Театр как способ лечения, 21 sierpnia 2015, http://gazeta.zn.ua/personalities/georg-zheno-teatr-kak-sposob-lecheniya-_html (dostęp: 20.03.2017). Praktycznie w każdym materiale drukowanym w prasie mówi się o ważnej funkcji terapeutycznej tej pracy: „Teatr przesiedleńców pracuje przede wszystkim z obawami ludzi. Ich przezwyciężenie możliwe jest poprzez dialog lub bolesną ekspresję. To właśnie na nich zbudowano fundamenty sztuk wystawianych w ramach projektu" - mówi Katarzyna Makarewska w artykule Театр переселения: психологічні та мистецькі ліки, http://cultua.media/teatr-pereselencja-psihologchn-ta-misteck-lki (dostęp: 20.03.2017).

10 Ю. Коваль, Кепка с карасями, Москва 2011.

11 D. LaCapra, Trauma, nieobecność, utrata, tłum. K. Bojarska, J. Burzyński et al., [w:] Antologia studiów nad traumą, red. T. Łysak, Kraków 2015, s. 66-67. 
śniejsze są sceny z przeszłości bohatera, tym bardziej traumatyczne wydaje się jego obecne życie. Jego historię można potraktować jako spotkanie z Ziemią Obiecaną, wygnanie z niej i tęsknotę za „złotym” czasem ludzkości. Jak pisze D. LaCapra:

Złoty czy też rajski wiek spełnia podobne funkcje, co boskość czy matka falliczna w tym sensie, że lokuje się go czy to jako domniemaną rzeczywistość czy jako fikcję u początków, które można albo odzyskać, albo przywrócić w jakiejś idealnej przyszłości ${ }^{12}$.

W tym sensie warto powiedzieć o wykorzystaniu w sztuce kategorii Raju: zarówno utraconego, jak i nieobecnego. Jaka jest różnica między utratą i nieobecnością? D. LaCapra proponuje taką interpretację: „typ nieobecności, który interesuje mnie najbardziej (choć nie wyłącznie), umieściłbym na poziomie ponadhistorycznym, zaś utratę - na poziomie historycznym"13. Faktycznie, główną kategorią w sztuce staje się Raj nieobecny, ukazany w sztuce jako teatralne powiadomienia o możliwości i jednocześnie braku istnienia terytorium absolutnej, wzajemnej miłości.

Chronotop ${ }^{14}$ wsi Czysty Dor, dokąd trafia narrator (aktor Witalij Linecki ${ }^{15}$ ), zyskuje w spektaklu te archetypowe cechy Raju nieobecnego. Jego fikcyjność została podkreślona wizualnie: postawiono na minimalistyczny design przestrzeni scenicznej jako konwencjonalnej sceny — jej szara i matowa kolorystyka odpowiada ponuremu stanowi umysłu bohatera: niezmienny, duży, fioletowy krąg słońca/księżyca w głębi sceny na tle błękitnego nieba $\mathrm{z}$ białymi chmurami sygnalizuje niepokój, lęk i pewną irracjonalność symulowanego obrazu. Jednak sposób myślenia i zbiorowego współistnienia bohaterów, ich naiwny i czysty światopogląd, dobrotliwy, ludowy humor, autentyczne pieśni oraz proste historie o najgłębszej treści scena po scenie tworzą osobliwą historię zauroczenia w świecie pełnym najprostszych przyjemności - najsmaczniejszego jedzenia w postaci wiadra ziemniaków, ogniska nad rzeką, łapania karpi, przewiezionej do sklepu deficytowej ceraty „w kwiatuszki” itp. Jest to świat, w którym drugoplanowe staje się głównym, a niepozornie wyglądający mieszkańcy wsi - pięknymi, bardzo uduchowionymi ludźmi. Kluczową i wyjątkową cechą tego świata jest panująca w nim całkowita empatia, obejmująca możliwość przyjęcia Innego (wędrowca lub sąsiada) i zdolność jego słuchania, a także wyspowiadania się mu i oddania czegoś najcenniejszego - zarówno w znaczeniu materialnym, jak i duchowym, wreszcie, zdolność do gry zbiorowej jako wspólnej twórczości dzieci i dorosłych. To właśnie empatia staje się tym, co wprowadza widza w zapro-

12 Ibidem, s. 69.

13 Ibidem, s. 65.

14 „Chronotop” (M. Bachtin) w tym wypadku rozumiany jest jako nierozerwalność czasowej i przestrzennej akcji scenicznej, która objawia się charakterystycznym tempem, rytmem, atmosferą, sposobem scenicznego zachowania bohaterów, zasadami mise-en-scène czy rozwiązaniami scenograficznymi.

15 Wybitny ukraiński aktor teatralny i filmowy, zmarł niedługo po premierze tego spektaklu (22.10.1971-16.07.2014). 
ponowane przez teatr zasady gry, jednocześnie budząc jego zdolność do wspólnego przeżycia tej historii powrotu, mówiąc za Freudem, do świata "przedgrzesznego", "przededypalnego".

Dojrzałość i umiejętności inscenizatorów pozwoliły im przez wiele tropów artystycznych (takich jak fioletowy księżyc/słońce, niebieskie, chłodne światło, nagle spowolniony ruch aktorów przy wejściu i wyjściu ze sceny) stworzyć dystans i dialog między symbolicznym (sioło jako Raj nieobecny) i quasi-rzeczywistym (pisarz-narrator z miasta, który przychodzi i odchodzi; to właśnie z jego goryczą i dramatem mógł przede wszystkim identyfikować się widz). Chodzi tutaj nie o konfrontację artysty i spektaklu z pozascenicznym doświadczeniem traumatycznym, lecz odwrotnie - o stworzenie mechanizmów przepracowania go. Totalny brak harmonii w życiu pozateatralnym reżyser kompensuje sobie bowiem poprzez modelowanie jej w przestrzeni teatru.

Mówiąc o funkcjach traumy i pracy z nią, D. LaCapra podkreśla różnicę między traumą strukturalną (ponadczasową, metafizyczną, wewnętrzną, trudno artykułowaną) a traumą historyczną (związaną z konkretnymi wydarzeniami historycznymi, ustaloną okolicznościami zewnętrznymi) ${ }^{16}$. Naukowiec skupia się zarówno na różnicy między tymi rodzajami traum, jak i na niebinarnym charakterze ich przeciwstawienia. Odwołując się do jego założeń badawczych, spektakl D. Bohomazowa można określić jako przykład pracy teatru z traumą strukturalną. Poprzez obraz Raju nieobecnego oraz powrót do archaicznych i naiwnych form reprezentacji życia w sztuce tej omówiono metafizyczne problemy braku ideału relacji międzyludzkich w społeczeństwie.

Jednak w spektaklu zawarte są również — choć mniej widoczne — przejawy traumy historycznej. Portretowanie bohaterów (fufajki, chłopskie buty), świat przedstawiony w spektaklu czy charakter „rozmów filozoficznych” wykazywały widoczną sowiecką genezę przestrzeni i bohaterów, nie pozwalając spektaklowi oderwać się od wbudowanej w prozie konkretyzacji czasu. „Pochodzenie radzieckie” tego świata paradoksalnie nie straszyło, a wzruszało, gdyż w spektaklu widziało się jako obraz zbiorowego dzieciństwa bliski dużej części współczesnych widzów. Reżyser występuje tutaj w roli swego rodzaju adwokata przeszłości. Idealizując ją, nakłania najpierw do zagłębienia się w tej „łasce” po to, żeby potem delikatnie, niewidocznie przenieść ten wyidealizowany obraz do puli pamięci zbiorowej. Chodzi tutaj o odtworzenie Raju utraconego w sensie historycznym, chociaż reżyser nie podejmuje w spektaklu żadnych tematów politycznych. Można raczej mówić o tworzeniu przez reżysera nowego przekazu o przeszłości, skierowanego do innej przyszłości, o czym pisze C. Caruth ${ }^{17}$.

Warto $\mathrm{w}$ tym miejscu podkreślić, że nadzwyczajnie sprawne i subtelne reżyserskie wyczucie czasu przełomowego $\mathrm{w}$ historii społeczeństwa $\mathrm{z}$ jego złożonością najnowszych, traumatycznych doświadczeń pozwoliło Bohomazowi uniknąć stwo-

\footnotetext{
16 D. LaCapra, op. cit., s. 98-99.

17 C. Caruth, op. cit., s. 133.
} 
rzenia ciężkiej atmosfery melancholii i beznadziejnej tęsknoty. Tutaj nie chodziło o utratę „łaski”, lecz o jej nieobecność. Pomimo całego życiowego zmęczenia składającego się na podstawę obrazu głównego bohatera oraz podstawową „otwartość”, niepełność narracji spektakl wywołał u widzów zaskakująco dobre emocje i spowodował powrót - choćby tymczasowy - radości życia, nawet w poczerniałym od popiołu Kijowie. Mechanizmy takiego wpływu najlepiej można opisać, przywołując słowa D. LaCapra:

Afirmacja nieobecności jako nieobecności, nie zaś jako utraty czy braku otwiera inne możliwości i domaga się innych sposobów radzenia sobie z problemami. Pozwala lepiej określić historyczne straty czy braki, które nie prowadzą do wymazania przeszłości. [...] Z historycznymi brakami czy stratami można radzić sobie w sposób, który w znacznym stopniu przyczyni się do poprawy warunków — istotnie wpłynie na podstawową transformację strukturalną — nie obiecując przy tym świeckiego zbawienia czy społeczno-politycznego powrotu do rzekomo utraconej (czy brakującej) jedności czy wspólnoty. Raj nieobecny to nie to samo, co raj utracony: nie trzeba uważać go za unicestwiony, by chcieć go odzyskać w jakiejś apokaliptycznej przeszłości czy we wzniosłej ślepej utopii, która w efekcie kreacji ex nihilo przyniesie całkowite odnowienie, zbawienie czy odkupienie. Nie tam należy szukać, ale zwrócić się ku innym, niezbawczym opcjom w życiu osobistym, społecznym i politycznym — opcjom innym, niż opuszczona przeszłość i pusta czy beznadziejna - a jednak jakoś tam przynosząca odkupienie przyszłość $^{18}$.

Jeżeli spektakl w reżyserii D. Bohomazowa wyraźnie udowodnia ważność empatii, to praca innego reżysera demonstruje konsekwencje jej braku.

Spektakl Spichlerz (Зерносховище) autorstwa Natalii Worożbyt został wystawiony na scenie 24 kwietnia 2015 roku i był pierwszym przedstawieniem tego utworu na Ukrainie. Sztukę opowiadającą o Hołodomorze na Ukrainie lat 19321933 autorka stworzyła na zlecenie Royal Shakespear Company, gdzie w 2009 roku odbyła się prapremiera.

Polistylistyczny utwór N. Worożbyt ma cechy kroniki historycznej, tragikomedii oraz misterium. Dzieło wyróżnia się postmodernistyczną nielinearnością i dość swobodnym korzystaniem z symboli - świątynia zamienia się tutaj w spichlerz, w którym przechowywane jest zabrane od rolników zboże, co jest metaforą pełnej dehumanizacji, śmierci duchowej i fizycznej.

Jeżeli Brytyjczycy, zlecając napisanie tekstu ukraińskiej autorce, pragnęli pokazać w Spichlerzu tragedię praktycznie nieznaną zachodniej publiczności, to reżyser Andrij Prychodko wybrał dla ukraińskich odbiorców nieoczekiwany sposób jej interpretacji. Konfrontując się zarówno z oficjalną, jak i prywatną pamięcią o Hołodomorze i jego ofiarach, wystąpił przeciwko procesom wiktymizacji w świadomości społeczeństwa i zdecydował się obwinić za wyniszczenie swego narodu same ofiary, zarzucając im niezdolność do przeciwstawiania się, słabość i tchórzostwo. Ukraińscy chłopi w spektaklu zostali przedstawieni jako ludzie tak karykaturalnie prymitywni, że aż momentami groteskowi. Ukraińska wieś (reprezentowana przez prawie 40 postaci w dramacie) jest tu pokazana jako bezosobowy bohater zbiorowy, kierujący się

18 D. LaCapra, op. cit, s. 75-76. 
jedynie zwierzęcymi instynktami stadnymi: przeżycia, strachu, podporządkowania silniejszemu. Jednocześnie kat i przestępca - komunista - zyskał wyraźne cechy ludzkie; jego postać jest rozbudowana psychologicznie, a on sam przedstawiany jako ofiara. Mimo to, z oczywistych powodów, widz nie może z nim sympatyzować, podobnie jak i z karykaturalnymi postaciami ukraińskich chłopów.

Wybierając taką nieoczekiwaną strategię pracy z traumą historyczną, reżyser wykazał własną niechęć/niezdolność/lęk do pracy z nią. Można założyć, że A. Prychodko, urodzony na wschodniej Ukrainie, gdzie doszło do tragedii Hołodomoru, sam jest nosicielem traumy transgeneracyjnej ${ }^{19}$. Jego wewnętrzna złość skierowana do „bezradnych” rodaków ujawnia się więc przez wypieranie dziedziczonych uczuć strachu, wstydu, upokorzenia, co prowadzi do przeniesienia poczucia własnej winy na same ofiary. Koncepcję reżysera można interpretować jako przejaw autoagresji, akt, w którym przez upokorzenie siebie, widza i własnej historii reżyser z całej siły pragnie uruchomić inne, alternatywne mechanizmy opracowania traumy historycznej. Trauma ta zniewala go jednak na tyle, że ujawnia jego niezdolność do empatii, pozbawiając „ofiarę" prawa do wyrażania bólu, a widza w sali — zdolności do przeżycia go, przekształcenia w żałobę i utratę, uwolnienia się od niego. A. Prychodko trzykrotnie apeluje przy tym do ustalonych performatywnych form społecznych uszanowania ofiar Wielkiego Głodu, otwierając i zamykając spektakl obrazami zapalonych świec na parapecie, a także karmiąc widzów rytualnym korowajem na zakończenie aktu. To wszystko pozwala mówić raczej o odgrywaniu traumy (co prowadzi widza do poczucia melancholii) niż o jej przepracowaniu, którego celem jest uwolnienie od afektów i traumatyzującej pamięci. O różnicach między tymi dwoma rodzajami pracy nad traumą $\mathrm{D}$. LaCapra pisze:

Odgrywanie i przepracowanie to z zasady procesy blisko ze sobą związane, ale analitycznie odmienne. Można dowodzić, że pożądana praktyka wymaga stworzenia takich warunków, w których przepracowanie, choć nigdy nie pokona siły odgrywania i przymusu powtarzania, może jednak przeciwdziałać, a przynajmniej minimalizować, aby stworzyć nowe szanse - nowe pole sił - w myśli i życiu, zwłaszcza empatyczne relacje zaufania, nieoparte na quasi-sakralnych procesach wiktymizacji i autowiktymizacji ${ }^{20}$.

Możliwość odgrywania obrazów przemocy prowadziła reżysera do ucieczki w podkreśloną teatralność i groteskę, które odgrywały tutaj - moim zdaniem rolę maski ukrywającej strach i niezdolność lub niechęć do mówienia o bólu oraz lęku ludzkim. Ta ucieczka w teatralność - choćby nawet bardzo atrakcyjną, artystyczną — jest metodą zbyt często używaną przez innych współczesnych ukraińskich reżyserów w pracy $\mathrm{z}$ traumą historyczną. W tym sensie warto wymienić również dwa

19 Odwołuję się tu do traumy Hołodomoru, która przez pół wieku politycznego tabu i wymuszonego milczenia ofiar została przekazana następnym pokoleniom, zwłaszcza mieszkańcom wschodu Ukrainy. W tej sytuacji można mówić o zatrzymaniu traumy i jej trwałym oddziaływaniu na przedstawicieli pokoleń „dzieci” i „wnuków” ofiar Hołodomoru.

20 D. LaCapra, op. cit., s. 91. 
spektakle młodego ukraińskiego reżysera Stanisława Żyrkowa (kierownika artystycznego Kijowskiego Teatru Miejskiego „Złote wrota”/“Золоті ворота” przygotowane na podstawie dramatów Pawła Arie. Prace tego popularnego dziś autora oferują nowy dla ukraińskiej dramaturgii, skomplikowany system interpretacji przeszłości traumatycznej, który opiera się na włączeniu empatii i połączeniu jej z życiowym podobieństwem, psychologizmem, a także elementami mistycyzmu irracjonalnego, a nawet eschatologicznego (Baba Prisia/Баба Прicя ${ }^{21}$ ), lub proponują wznieść się ponad ideologiczny rozłam społeczeństwa, przepracowując te traumy przez przebaczenie i akceptację pozycji Innego (Chwała bohaterom!/Слава Героям!). Stołeczny reżyser S. Żyrkow skupiony jest przede wszystkim na tworzeniu konkurencyjnego produktu artystycznego, nie na pracy z traumą. Jednak na podstawie tych samych dwóch utworów dramatycznych reżyser Ołeksij Krawczuk we Lwowskim Teatrze im. Łesi Ukrainki niemal równocześnie z kijowskimi premierami wystawił w latach 2015-2016 swoje spektakle. Warto tu wspomnieć, że jego dzieje symbolicznie obejmują całą Ukrainę z zachodu na wschód, czego nie można prawdopodobnie powiedzieć o żadnym innym reżyserze. Wieloletnie doświadczenie w pracy w teatrach we Lwowie, Charkowie, Dniepropietrowsku, Doniecku, Ługańsku, teatralne szkoły letnie na Krymie, przebywanie na terytoriach okupowanych przez prorosyjskich bojowników, gdzie Krawczuk przez jakiś czas kierował Ługańskim Teatrem Lalek, perypetie wyjścia z tych obszarów wojennych latem 2014 roku - to wszystko wykształciło u artysty należącego do reżyserów w średnim wieku — głęboko osobisty i niepowtarzalny punkt widzenia na problemy ukraińskiego społeczeństwa.

Zarówno filozofia życiowa Krawczuka, jak i filozofia jego spektakli opiera się na pogodzeniu i akceptacji walczących stron, lecz także na przebaczeniu. Przy tym w wyniku osobistych i przepracowanych sytuacji traumatycznych dąży do wysokiego stopnia symbolizacji przeżytego doświadczenia. W związku z tym nazwa spektaklu o zmarginalizowanej rodzinie, która mieszka w strefie czarnobylskiej (premiera 20 lutego 2015 roku) brzmi ogólnie: Baba, a nie Baba Prisia. Aktor Oleh Stefan grający rolę osiemdziesięcioletniej staruszki przedstawia wszystkie paradoksy naszej rzeczywistości, w której kobieta jest jednocześnie mężem, babcia — wojownikiem-mścicielem, a strefa Czarnobyla - ostatnim miejscem ratunku ludzi odrzuconych przez społeczeństwo.

Jednakże najbardziej produktywnie pomysł reżyserski zaczął funkcjonować w spektaklu Chwała bohaterom! (premiera 31 stycznia 2016 roku). W ślad za dramaturgiem, A. Krawczuk skupił się na losach dwóch weteranów II wojny światowej, dokładnie i delikatnie pokazując razem z aktorami - O. Stefanem i Jurijem Chwostenkiem - drogę od ich sprzeciwu wobec ideologii komunistycznej i nacjonalistycznej do pogodzenia i wzajemnej pomocy. Reżyser podaje unikalny dla naszego społeczeństwa przykład pracy z przeszłością. Podobnie jak dramaturg twierdzi, że „przeszłość zabija”, co symbolizują postaci żołnierzy z karabinami, którzy momentami

21 П. Ар'є, Баба Пріся та інші герої, Івано-Франківськ 2015. 
pojawiają się na scenie i strzelają. Dla reżysera najważniejsze jest doprecyzowanie tego stwierdzenia: „nieodpuszczona, nieprzebaczona przeszłość zabija”. Dlatego wysuwa na pierwszy plan historię drugorzędnej bohaterki dramatu — trzydziestoletniej pielęgniarki, wnuczki weterana UPA. Dziewczyna ta (Marja Horodeczna) całkowicie odrzuciła życie osobiste, aby poświęcić się jedynej osobie z rodziny — dziadkowi. W finale dorasta ona jednak do otwartej konfrontacji ze skorumpowanym systemem medycznym i, co najważniejsze, uświadamia sobie potrzebę, by żyć dla siebie i mieć rodzinę, a zatem - przyszłość. Jej monolog końcowy reżyser traktuje jako symboliczne wyzwolenie od fatalnych więzi z przeszłością: dziękując swojemu dziadkowi i wyrażając całą swoją miłość do niego, dziewczyna mówi jednak o gotowości spotkania innego, młodego mężczyzny, z którym założy rodzinę i będzie mieć dzieci. Tą emfazą w końcu spektaklu reżyser akcentuje konieczność „przerwania” zamkniętego kręgu niekończących się kompleksów związanych z przeszłością i nieprzepracowaną traumą. Oddając hołd i cześć przeszłości, uświadamiając sobie całą gorycz ostatnich strat — zapewnia A. Krawczuk — jednocześnie potrzebujemy nabrać dystansu i pozwolić sobie na odpuszczenie grzechów przeszłości. Tylko tak możemy uwolnić się od traum transgeneracyjnych, które kierują nami do dzisiaj.

Kategoria straty, jako jedna z podstawowych w pracy z historyczną przeszłością, nagle uwydatniona została podczas premiery sztuki Zimowa opowieść Williama Szekspira (Winter's Tale) Lwowskiego Teatru Akademickiego im. Łesia Kurbasa (premiera 27 marca 2016 roku). Reżyser Eugeniusz Chudzyk zaproponował niezwykłą inscenizację: na wydarzenia i bohaterów szekspirowskiej tragikomedii spojrzał jako na historię Ukrainy od średniowiecza do chwili obecnej. Linearny czas historyczny (Starożytna Ruś, Kozactwo, XIX wiek, modernizm, współczesność), zasygnalizowany jedynie elementami strojów oraz wstawkami wokalnymi, splata się tutaj z cyklicznym czasem mitologicznym opowieści. Historia królewskiej córki Straty, poddanej wygnaniu i szczęśliwie odnalezionej po wielu latach, w końcowej scenie spotkania z matką pokazana jest jako niezwykle aktualna i bolesna: „Pływe kacza”, która stała się pieśnią żałobną za zmarłymi na Majdanie, a następnie za żołnierzami ATO, brzmi tu nie tyle jak requiem dla zmarłych, ile oznaczenie momentu spotkania Ukrainy ze sobą, ze swoim prawdziwym „ja” ukształtowanym nieskończoną liczbą traum i strat historycznych, a jednocześnie przygotowanym i potrafiącym zatrzymać ich niekończące panowanie przez zjednoczenie, pogodzenie, spokój.

Można powiedzieć, że w teatrze ukraińskim zaczął się nowy dla naszej kultury scenicznej etap - tworzenia narracji traumy. Jego aktywnymi twórcami są przedstawiciele nowej generacji dramaturgów, przeważnie po trzydziestce, którzy mają nowoczesny styl pisania oraz doświadczenie pobytu i pracy za granicą, a także są aktywnie zaangażowani w rozwój nowych form działalności teatru, również dokumentalnego. Z kolei reżyserzy, których spektakle, moim zdaniem, prowadzą do udanego przepracowania doświadczeń traumatycznych na podstawie utworów tych dramaturgów, należą do poprzedniej, nieco starszej generacji ludzi po pięćdziesiątce, która kształtowała się na przełomie lat osiemdziesiątych i dziewięćdziesiątych XX 
wieku i ma doświadczenie życiowe w dwóch formacjach historycznych. Można zauważyć, że traumy historyczne udaje się dziś skuteczniej przepracować autorom, którzy należą do generacji młodych, poniezależnościowych ludzi, podczas gdy reżyserzy teatralni muszą być raczej częścią nieco starszego pokolenia, mieć głębsze „zaplecze” historyczne i światopoglądowe.

Z punktu widzenia metodologii należy zauważyć, że wymienione dzieła teatralne podkreślają możliwość i wagę sztuki teatralnej w mierzeniu się z traumatycznym doświadczeniem widzów. Empatia, którą D. LaCapra określa jako „rodzaj wirtualnego doświadczenia, poprzez które »ja» stawia się w sytuacji innego, rozumiejąc i uznając różnice jego sytuacji, a przez to nie zajmując jego miejsca"22, stanowi bowiem podstawę tego rodzaju komunikacji kulturowej. O znaczeniu empatii jako części składowej pracy z historycznymi i strukturalnymi traumami pisze D. LaCapra, skupiając się na jej szczególnej funkcji ochrony reprezentacji traumatycznego doświadczenia przez uproszczone, optymistyczne wzorce (tak charakterystyczne dla ukraińskiego teatru).

Empatia odgrywa istotną rolę w próbach zrozumienia wydarzeń traumatycznych i ofiar traumy. Może (powinna, jak sądzę) też przejawiać się w warstwie stylistycznej, w sposobie pojmowania i podejmowanie pewnych kwestii. Stanowi ona zagrożenie dla fetyszyzujących i totalitaryzujących narracji negujących traumę, która powołała je do życia poprzez przedwczesny powrót do zasady przyjemności, harmonię wydarzeń, a często też naprawianie przeszłości w kategoriach podnoszących na duchu komunikatów czy optymistycznych, egoistycznych scenariuszy ${ }^{23}$.

Jak pokazuje praktyka, spektakle, które ignorują lub negują niezbędność empatii, odsuwają przepracowywanie traum historycznych na przyszłość, nie zmieniając stosunku publiczności do przeszłości lub teraźniejszości. Jednak w kontaktach $\mathrm{z}$ traumą historyczną z artystycznego i psychologicznego punktu widzenia to właśnie możliwość współprzeżycia i współczucia sprawia, że teatr jest jednym z najbardziej skutecznych sposobów zbiorowego przepracowywania doświadczeń traumatycznych.

Tłumaczenie z języka ukraińskiego: Aleksandra Koszela, Mateusz Świetlicki i Wasyłyna Konduch

\section{Bibliografia}

Alexander J., Cultural trauma and collective identity, [w:] The Meaning of Social Life. A Cultural Sociology, Oxford University Press, Oxford 2003.

Caruth C., Teoria traumy jako siła lektury. Cathy Caruth w rozmowie z Katarzyna Bojarska, rozm. przepr. K. Bojarska, „Teksty Drugie” 2010, nr 6, s. 125-136.

Erickson K., A New Species of Trouble: The Human Experience of Modern Disasters, Norton, New York 1994.

Коваль Ю., Кепка с карасями, Детская литература, Москва 2011.

${ }^{22}$ D. LaCapra, op. cit., s. 100.

23 Ibidem.

Miscellanea Posttotalitariana Wratislaviensia 6/2017

(C) for this edition by CNS 
LaCapra D., Trauma, nieobecność, utrata, [w:] Antologia studiów nad traumą, tłum. K. Bojarska, J. Burzyński et al., red. T. Łysak, Universitas, Kraków 2015.

Niziołek G., Polski teatr Zagłady, Wydawnictwo Krytyki Politycznej, Warszawa 2013.

Ар'є П., Баба Пріся та інші герої, Дискурс, Івано-Франківськ 2013.

Жено Г., Театр как способ лечения, 21 sierpnia 2015, http://gazeta.zn.ua/personalities/georg-zheno-teatr-kak-sposob-lecheniya-_.html.

Макаревська К., Театр переселения: психологічні та мистеиьькі ліки, 30 listopada 2015, http:// cultua.media/teatr-pereselencja-psihologchn-ta-misteck-lki.

Przyjęto do druku/Accepted for publication: 5.02.2017 